\title{
Oncogenes and anti-oncogenes in tumorigenesis
}

\author{
R Monier \\ Institut Gustave-Roussy, UA CNRS 1158, Laboratoire d'Oncologie moléculaire, \\ 39, rue Camille Desmoulins, 94805 Villejuif cedex, France \\ (15th meeting of the INRA development group, Paris, 24-26 May 1989)
}

\begin{abstract}
Summary - Recent advances have led to the identification of cellular genes which are involved in the initiation and progression of tumorigenesis. The proto-oncogenes, which normally participate in the regulation of cell proliferation and differentiation, can become oncogenes through alterations in the regulation of their expression and/or their coding sequences. Their contribution to the tumorigenic phenotype is dominant. The anti-oncogenes or tumor suppressor genes or recessive oncogenes are normally implicated in a negative regulation of cellular proliferation. The loss of their activity contributes to tumorigenesis in a recessive manner. Genetic events activating proto-oncogenes or inactivating anti-oncogenes accumulate in the same cell during tumor progression and co-operate to determine the malignant invasive phenotype of advanced tumors.
\end{abstract}

oncogene / anti-oncogene

Résumé - Oncogènes et anti-oncogènes dans la tumorigenèse. L'utilisation des méthodes de la génétique moléculaire a conduit à l'identification de deux classes de gènes cellulaires, qui interviennent dans l'initiation et la progression des tumeurs humaines. Les proto-oncogènes participent à l'oncogenèse après activation par un événement génétique qui altère leur expression et/ou la structure de leur produit. Leur participation au déterminisme du phénotype tumoral présente un caractère dominant. Les anti-oncogènes, dont le prototype est le gène Rb impliqué dans la transmission héréditaire du rétinoblastome codent probablement pour des produits qui interviennent dans un contrôle négatif de la prolifération cellulaire. C'est donc leur perte ou leur inactivation qui intervient dans le processus oncogène, de façon récessive. L'exemple d'une tumeur humaine fréquente, le cancer du colon, montre que les inactivations d'anti-oncogènes sont au moins aussi importantes pour conduire à la malignité que les activations de proto-oncogènes.

oncogène / anti-oncogène

\section{INTRODUCTION}

Recent progress, following the introduction of molecular genetics methods, has permitted the identification of some of the genes which might be involved in the initiation and progression of tumorigenesis. Some of these genes are cellular genes, the proto-oncogenes, which normally function in the regulation of cellular prolife- ration and differentiation. Through alterations in the regulation of their expression and/or in their coding sequences, these proto-oncogenes are activated into oncogenes, whose persistent expression contributes to the tumorigenic phenotype in a dominant manner.

The study of some cancers, which can occur in hereditary forms, has led to the identification of another class of genes, 
whose alterations appear to be equally important in tumorigenesis. These so-called anti-oncogenes or tumor suppressor genes or recessive oncogenes are probably implicated in a negative regulation of cellular proliferation. Their normal activity therefore tends to limit cell growth and it is the loss of this activity which indeed contributes to tumorigenesis. The genetic events which affect them are recessive and both alleles of the gene in diploid cells need to be lost or otherwise rendered inactive, in order to contibute to the tumorigenic phenotype.

\section{THE PROTO-ONCOGENES}

More than 50 genes have been identified in animals and in human tumors as protooncogenes and there is no reason to believe that this list is closed. Many of these genes are recognized as proto-oncogenes because of their aptitude to transform cells in culture or to induce tumors in animal models or because they are frequently re- arranged or amplified in human tumors, although their biochemical properties and biological functions remain unknown. Nevertheless, about half of the proto-oncogenes identified at the present time are known to code either for growth factors or for elements of the cellular machinery which enable cells to recognize growth factors and to translate the information communicated by growth factors into cellular responses (table I).

Genes coding for membrane receptors are well represented in the proto-oncogene class. All of them code for integral membrane proteins, with an extracellular receptor domain and an intracellular domain possessing a tyrosine protein kinase activity. The ligands for only 2 of these protooncogenes are known: the c-erb-B1 gene codes for the receptor of EGF and the cfms gene codes for the receptor of M-CSF (CSF-1). All the other proto-oncogenes of this class are included in the receptor gene category, because of sequence similarities with known receptor genes. The lack of knowledge about possible ligands is partic-

Table l. Proto-oncogene products.

\begin{tabular}{ll}
\hline Proto-oncogene & Product \\
\hline int-2, hst, fgf-5, sis & Growth factor \\
$\begin{array}{l}\text { erb-B1, erb-B2, fms, met, } \\
\text { kit, trk, sea, ros }\end{array}$ & $\begin{array}{l}\text { Growth factor receptor } \\
\text { with tyrosine-protein kinase activity } \\
\text { mas } \\
\text { src, yes, fes, fps, fgr, abl, lck }\end{array}$ \\
$\begin{array}{l}\text { Angiotensin receptor } \\
\text { Ha-ras, Ki-ras, N-ras }\end{array}$ & Membrane-bound tyrosine protein kinase \\
fos, jun, myb & $\begin{array}{l}\text { Membrane-bound GTPase } \\
\text { Cytoplasmic serine-threonine-protein kinase }\end{array}$ \\
erb-A & Nuclear transcription factors \\
myc & Thyroid hormone receptor \\
\end{tabular}


ularly frustrating in the case of the c-erbB2 gene, because of its implication in human breast tumorigenesis and of its importance as a marker with prognostic value (Slamon et al, 1987; Guérin et al, 1988; King et al, 1989; Tsuda et al, 1989; Wright et al, 1989).

Some proto-oncogenes, such as c-fos, c-jun or c-myb code for nuclear phosphoproteins, whose production and/or activity are modulated in response to the binding of growth factors to their membrane receptors.

A particularly interesting case is represented by the c-erb-A proto-oncogene, which codes for 1 form of the thyroid hormone receptor. Recent data (Damm et al, 1989) have shown that the activated oncogene, v-erb-A, transduced by the avian erythroblastosis virus, contributes to erythroblast transformation by blocking thyroidhormone-induced differentiation. The verb-A product has kept the DNA binding activity of the normal thyroid-hormone receptor but has lost its ability to bind the thyroid hormone. As a consequence, $v$ erb-A functions as a constitutive repressor of triiodothyronine responsive genes. It represents therefore the first example of dominant negative oncogenes, predicted on theoretical grounds by Herskowitz (1987).

The precise function of the c-myc gene, whose activity is associated with cellular proliferation and which has so often been implicated in human tumors, still constitutes an enigma: it is not clear as yet as to whether its product directly participates in DNA replication (Iguchi-Ariga et al, 1987) or in the regulation of gene expression (Kingston et al, 1984) at the transcriptional (Onclerq et al, 1988) or post-transcriptional level (Prendergast and Cole, 1989).

Little is known about the precise pathways through which the signals transduced through the plasma membrane by mem- brane receptors are transmitted to the nucleus to activate gene expression and DNA replication. Protein kinases located in the cytoplasm are probably involved and one good candidate is the product of the $c$ raf proto-oncogene, which encodes such a serine-threonine protein kinase. Recent data (Morrison et al, 1988; Wasylyk et al, 1989) show that its kinase activity is increased in response to growth factor stimulation and that the expression of the raf oncogene activates transcription from promoter elements recognized by the products of the nuclear proto-oncogenes $c-j u n /$ c-fos.

Several proto-oncogenes code for proteins which bind to the cytoplasmic side of the plasma membrane, after posttranslational addition to their peptide structure of a hydrophobic chain (Buss and Sefton, 1985; Hancock et al, 1989). Some of them (eg c-src) code for tyrosine-protein kinases, while the ras genes code for proteins of $21 \mathrm{kDa}$ with sequence similarities to the $\alpha$-subunit of $G$ proteins which bind and hydrolyze GTP. The function of these proto-oncogenes remains unclear, although their implication in the process of signal transduction is probable. It has been suggested that tyrosine-protein kinases of the src family are partners of cytokine membrane receptors which have no tyrosine-protein kinase domain of their own. Recently, evidence supporting this hypothesis has been provided for $c-l c k$, which is expressed in T-lymphocytes and whose kinase activity is increased in response to $\mathrm{T}$ cell activating signals (Veillette et al, 1989).

\section{THE ANTI-ONCOGENES}

The existence of anti-oncogenes or tumor suppressor genes was postulated on the basis of 2 types of observations : 
- it has frequently been observed that hybrid cells, resulting from the fusion of a tumor cell with a normal cell, are not able to grow as tumors when injected into immuno-compromised animals (Stanbridge, 1987). The tumorigenic phenotype in these experiments is therefore recessive and the normal cell is supposed to express genes, which suppress the tumorigenic phenotype.

- Evidence has been accumulating in recent years to the effect that the proliferation of normal cells is regulated by cytokines, some of which stimulate cell division while others exert a negative effect on cell growth (Sporn and Roberts, 1988). This dual type of regulation leads to the prediction that deregulated proliferation, as observed in transformed and tumor cells, could be the result either of an excess of proliferative signals or of the loss of negative regulation.

\section{THE Rb GENE}

The identification of the first anti-oncogene actually stemmed from the study of one particular cancer, retinoblastoma, which occurs either in hereditary or sporadic form in young children.

An epidemiological study of retinoblastoma enabled Knudson (1971) to propose that the appearance of the tumor requires 2 genetic events occurring successively in the same retina precursor cell. In hereditary cases, 1 of these 2 genetic changes is already present in the germ line and is the cause of the hereditary transmission of retinoblastoma. The second genetic event occurs in a somatic cell and, when it has occurred in a retina precursor cell, a retinoblastoma is produced. Further cytogenetic and gene linkage studies identified a locus on chromosome 13 p 14 as linked to the hereditary predisposition to retinoblas- toma. The cloning of the retinoblastoma (Rb) gene (Friend et al, 1986; Lee et al, 1987) established that the 2 genetic events postulated by Knudson actually affect the same locus on each of the 2 chromosomes 13 in diploid cells and amount to the complete loss or inactivation of the $2 \mathrm{Rb}$ alleles.

The $R b$ gene covers about $200 \mathrm{~kb}$ and is comprised of 27 exons (Hong et al, 1989; T'Ang et al, 1989). Its promoter region has no recognizable TATA or CAAT boxes, but possesses an Sp I transcription factor binding site, and a GC-rich domain, ie it has the characteristic features of house keeping gene promoters. The $R b$ gene is transcribed as a $4.6 \mathrm{~kb} \mathrm{mRNA}$, and its protein product is a $105 \mathrm{kDa}$ phosphorylated polypeptide located in the nucleus. The $\mathrm{Rb}$ protein is subject to a cycle of phosphorylation-dephosphorylation which is coupled to the cell cycle (Ludlow et al, 1989).

Thus, in the retinoblastoma case, tumorigenesis is the result of the inactivation of 1 particular gene, the $R b$ gene, and not of the activation of proto-oncogenes. The $R b$ gene is at the moment the best example of a gene whose activity is antagonistic to tumor development, ie of an anti-oncogene or tumor suppressor gene.

The $R b$ gene, which is responsible for the hereditary predisposition to retinoblastoma, predisposes also to osteosarcomas and, possibly, melanomas as observed in survivors of hereditary retinoblastomas (Murphree and Benedict, 1984; Hansen et al, 1985). However, its inactivation may also take part in the progression of other tumors, since several recent observations have demonstrated that the $R b$ gene is not only inactivated in all retinoblastomas, but also in a fraction of small cell lung cancers (Harbour et al, 1988) and breast cancers (Lee et al, 1988; T'Ang et al, 1988). 
Moreover, it has now been shown that the transforming proteins of several DNA tumor viruses (SV40 large $T$, Polyoma large T, Adenovirus 5 E1A, HPV -6 and HPV-16 E7) (De Caprio et al, 1988; Whyte et al, 1988; Dyson et al, 1989) bind to the unphosphorylated form of the $\mathrm{Rb}$ protein (Ludlow et al, 1989). Some mutants of SV40 $\mathrm{T}$ and adenovirus $5 \mathrm{E} 1 \mathrm{~A}$, which are inactive in transformation are aiso unable to bind the $\mathrm{Rb}$ protein. Therefore, it is likely that the formation of complexes between the viral transforming proteins and the $\mathrm{Rb}$ protein plays a role in transformation. It can be suggested that the viral protein act, at least in part, by preventing the $R b$ gene from playing its normal role in the regulation of cellular division.

\section{THE p53 GENE}

Another likely example of anti-oncogenes is the gene coding for the nuclear phosphoprotein $p 53$. The $p 53$ gene was previously considered as a proto-oncogene, because it apparently co-operated with the Ha-ras oncogene in rodent cell transformation (Eliyahu et al, 1984; Parada et al, 1984). However, it was recently discovered that the particular p53 cDNA clone used in co-transformation experiments was a mutated form of the normal gene, which is itself devoid of co-operating activity (Hinds et al, 1989). Moreover, there are several examples of tumorigenic cell lines in which the p53 gene is lost or otherwise inactivated (Wolf and Rotter, 1985; Masuda et al, 1987; Ben-David et al, 1988; Hicks and Mowat, 1988) and it has already been known for several years that p53 forms complexes with SV40 large T (Lane and Crawford, 1979) and adenovirus 5 E1B (Sarnow et al, 1982) in cells transformed by $S V 40$ and adenovirus 5 , respectively. It also forms complexes in vitro with the E6 protein of HPV16 (Howley, personal communication). For all these reasons, it is likely that the $p 53$ gene, which maps to human chromosome $17 \mathrm{p}$ (Miller et al, 1986) is in fact an anti-oncogene and not a protooncogene (Finlay et al, 1989). If this is true, it shows that anti-oncogenes can be confused with proto-oncogenes, because some of their mutants are able to exert a dominant negative effect.

\section{THE Krev-1/rap-1 GENE}

Many attempts to find tumor suppressor genes by transfecting DNA from normal cells into transformed cell lines and looking for morphological revertants have been made. One of these attempts succeeded in identifying the murine $K r e v-1$ gene, a gene which could code for a protein of 184 aminoacids with several similarities to Ha-rasp21 and which can revert to "flat" morphology NIH 3T3 cells transformed by the Kirsten strain of murine sarcoma virus (Kitayama et al, 1989). The Krev-1 gene is identical to rap-1, a member of the ras gene family, previously cloned by Pizon et al (1988).

\section{ANTI-ONCOGENES IN OTHER HEREDITARY TUMORS}

Besides retinoblastoma, there are several other examples of tumors, the predisposition of which is transmitted from parents to children through the germ line. For some of them, linkage studies and DNA restriction fragment length polymorphism have permitted the identification of chromosome regions in which the predisposing genes are located (table II). At the moment, it is usually assumed that these genes should be anti-oncogenes as is the case for retinoblastoma. 
Table II. Chromosome loci associated with inherited predispositions to cancers.

\section{Tumor}

\section{Chromosome loci}

Retinoblastoma/Osteosarcoma

Wilms' tumor associated with:

WAGR syndrome

Beckwith-Wiedeman syndrome

Multiple endocrine neoplasia, 2A

Neurofibromatosis Type 1

Neurofibromatosis Type 2

Polyposis coli

Von Hippel-Lindau syndrome
$13 \quad$ q14

11 p13

11 p15

10 p11.2-q11.2

17 q12-q22

$22 \quad q 11.1-q 13.1$

5 q21-q22

3 p25
Nevertheless, it should be pointed out that none of the hypothetical antioncogene has been identified and cloned as yet and there are indications that genetic mechanisms involved in hereditary tumors other than retinoblastoma might be more complicated. In the case of the Wilms' tumors of the kidney, 2 loci on chromosone 11,1 at $11 p 13$ and the other at 11 p 15 are linked to the genetic predisposition. The existence of a 3rd locus, which has not been located as yet, has recently been recognized (Grundy et al, 1988; Huff et $a l, 1988$ ). It is equally possible that, in other hereditary tumors, the predisposing gene be of the proto-oncogene type, rather than of the anti-oncogene type.

\section{ALLELE LOSSES IN HUMAN COMMON CANCERS}

The use of restriction fragment length polymorphism has shown that, in many human tumors, large deletions of well-defined chromosome regions are frequently observed (table III). It is suspected that the chromosome regions where these deletions occur contain alleles of antioncogenes, which are thus lost in the tu- mor cells. In 2 cases, hypotheses can be formulated with regard to the identity of the postulated anti-oncogenes: allele losses on the long arm of chromosome 13 could affect the $R b$ gene while those occurring on the short arm of chromosome 17 could entail the loss of a p53 gene allele (Baker et al, 1989).

Colorectal cancer is a good example of a common human tumor, for which the respective contributions of oncogene activation and allele losses to tumor progression have been carefully studied (Vogelstein et al, 1988). Most colorectal carcinomas appear to arise from adenomas, which can themselves be classified in classes representing successive steps in the transition from the normal epithelium to the malignant tumor. Moreover, familial adenomatous polyposis is a hereditary condition which predisposes to the development of many colorectal adenomas in affected persons. The locus (fap) segregating with this disease has been mapped to the long arm of chromosome 5 (Herrera et al, 1986; Bodmer et al, 1987; Leppert et al, 1987). The determination in tumors at different levels of progression of the respective frequencies of allelic losses on chromosomes 5,17 and 18 and of activation of the Ki-ras 
Table III. Allelic losses in human tumors (detected by restriction fragment length polymorphism).

Tumor

Chromosome sites

\begin{tabular}{ll} 
Bladder & $11 p$ \\
Breast & $11 p, 13 q, 17 p$ \\
Colon & $5 q, 17 p, 18 q$ \\
Gliomas (esp. astrocytomas) & $17 p$ \\
Renal cell carcinoma & $3 p 14-p 25$ \\
Lung & \\
$\quad$ small cell lung carcinomas & $3 p 14-p 25,13 q, 17 p$ \\
$\quad$ others & $3 p, 11 p t e r-p 15.5$, \\
Parotid gland & $11 p 13-q 13,13 q, 17 p$ \\
Stomach & $3 p 14-p 25$ \\
Thyroid (medullary) & $11 p$ \\
Uterine cervix & $1 p$ \\
\hline
\end{tabular}

proto-oncogene has led Vogelstein et al (1988) to suggest that in patients without familial polyposis, the somatic loss of 1 allele at the fap locus could be the 1st event leading to an inefficient control of cellular proliferation. In many patients, the appearance of a fully malignant tumor would result from the accumulation in the same cell of the fap allele loss, a Ki-ras gene mutation, the allelic loss of chromosome $18 \mathrm{q}$ sequences and the allelic loss of chromosome $17 p$ sequences occurring in that order.

Classical epidemiological studies of colorectal cancers have already suggested that the appearance of a malignant carcinoma requires the accumulation of 5-6 genetic events in the same cell (Cairns, 1978). Recent molecular genetic studies therefore confirm the multi-step nature of colorectal tumor progression and have permitted the identification of 4 different genetic alterations associated with these tumors. The fact that amongst these 4 alterations, 3 are likely to correspond to the loss of anti-oncogenes and 1 is a proto-oncogene mutation underlines the im- portance of anti-oncogene inactivation in 1 common cancer.

Another intriguing aspect of these data is that, even though ras mutations occur in about $50 \%$ of all tumors examined, it remains that, in the other $50 \%$, no ras gene mutation was observed. The identification of the genetic event which can substitute for the ras gene mutation is evidently a high priority goal. Similarly, allelic losses on chromosomes 5, 18 and 17 do not occur in all tumors, nor do they always occur in the order described above for some of the tumors. It would be of evident clinical interest to distinguish between 2 possible hypotheses. The 1st hypothesis would suggest the existence of a panel of genetic alterations, some of which, in different combinations, would lead to the appearance of tumors with identical pathological presentations. The 2nd hypothesis states that different combinations of genetic alterations actually produce phenotypically different tumors that we are not able to recognize as pathological entities because of the relative inefficiency of our present techniques. 
The second hypothesis is already supported by studies which attribute significant prognostic value to observations on the state and expression of some oncogenes in common human cancers.

\section{REFERENCES}

Baker SJ, Fearon ER, Nigro JM, Hamilton SR, Preisinger AC, Jessup JM, Van Tuinen $P$, Ledbetter DH, Barker DF, Nakamura Y, White R, Vogelstein B (1989) Chromosome 17 deletions and p53 gene mutations in colorectal carcinomas. Science 244, 217-220

Ben-David Y, Prideaux VR, Chow V, Benchimol $S$, Bernstein A (1988) Inactivation of the $p 53$ oncogene by internal deletion of retroviral integration in erythroleukemic cell lines induced by Friend leukemia virus. Oncogene 3,179-185

Bodmer WF, Bailey CJ, Bodmer J, Bussey HJR, Ellis A, Gorman P, Lucibello FC, Murday VA, Rider SH, Scambler P, Sheer D, Solomon E, Spurr NK (1987) Localization of the gene for familial adematous polyposis on chromosome 5. Nature 328, 614-616

Buss JE, Sefton BM (1985) Myristic acid a rare fatty acid is the lipid attached to the transforming protein of Rous sarcoma virus and its cellular homolog. $J$ Virol $53,7-12$

Cairns J (1978) In: Cancer: Science and Society. Freeman, San Franciso, 37

Damm K, Thompson CC, Evans RM (1989) Protein encoded by $v$-erb-A functions as a thyroid-hormone receptor antagonist. Nature 339, 593-597

De Caprio JA, Ludlow JW, Fiage J, Shew JY, Huang CM, Lee WH, Marsilio E, Paucha E, Livingston DM (1988) SV40 large T antigen forms a specific complex with the product of the retinoblastoma susceptibility gene. Cell $54,275-283$

Dyson N, Howley P, Münger K, Harlow E (1989) The human papillomavirus-16 E7 oncoprotein is able to bind to the retinoblastoma gene product. Science 243, 939-937

Eliyahu D, Raz A, Gruss P, Givol D, Oren M (1984) Participation of p53 cellular tumor antigen in transformation of normal embryonic cells. Nature 312, 646-649
Finlay CA, Hinds PW, Levine AJ (1989) The p53 proto-oncogene can act as a suppressor of transformation. Cell 57, 1083-1093

Friend SH, Bernards R, Rogelj S, Weinberg RA, Rapaport JM, Albert DM, Dryja TP (1986) A human DNA segment with properties of the gene that predisposes to retinoblastoma and osteosarcoma. Nature 323, 643-646

Grundy P, Koufos A, Morgan K, Li FP, Meadows AT, Cavenee WK (1988) Familial predisposition to Wilms' tumour does not map to the short arm of chromosome 11. Nature 336, 374-376

Guérin $M$, Barrois $M$, Terrier $M J$, Spielman $M$, Riou G (1988) Overexpression of either c$m y c$ or c-erb-B-2/neu proto-oncogenes in human breast carcinomas: correlation with poor prognosis. Oncogene Res 3, 21-31

Hancock JF, Magee Al, Childs JE, Marshall CJ (1989) All ras proteins are polyisoprenylated but only some are palmitoylated. Cell 57 , 1167-1177

Hansen MF, Koufos A, Gallie BL, Phillips RA, Fodstad O, Brogger A, Gedde-Dahl T, Cavenee WK (1985) Osteosarcoma and retinoblastoma: a shared chromosomal mechanism revealing recessive predispositions. Proc Natl Acad Sci USA 82, 6216-6220

Harbour JW, Lai SL, Whang-Peng J, Gazdar AF, Minna JD, Kaye FJ (1988) Abnormalities in structure and expression of human retinoblastoma gene in SCLC. Science 241, 353357

Herrera L, Kakati S, Gibas L, Pietrzak E, Sandberg AA (1986) Brief clinical report: Gardner syndrome in man with an interstitial deletion of 5q. Am J Med Genet 25, 473-476

Herskowitz I (1987) Functional inactivation of genes by dominant negative mutations. $\mathrm{Na}$ ture 329, 219-222

Hicks GG, Mowat M (1988) Integration of Friend murine leukemia virus into both alleles of the p53 oncogene in an erythroleukemic cell line. $J$ Virol 62, 4752-4755

Hinds $P$, Finlay C, Levine AJ (1989) Mutation is required to activate the p53 gene for cooperation with the ras oncogene and transformation. J Virol 63, 739-746

Hong FD, Huang HJS, To $H$, Young LJS, Oro A, Bookstein R, Lee EYHP, Lee WH (1989) Structure of the human retinoblastoma gene. Proc Natl Acad Sci USA 86, 5502-5506 
Huff V, Compton DA, Chao LY, Strong LC, Geiser CF, Saunders G (1988) Lack of linkage of familial Wilm's tumour to chromosomal band 11 p13. Nature 336, 377-378

Iguchi-Ariga SMM, Itani T, Kiji Y, Ariga H (1987) Possible function of the c-myc product: promotion of cellular DNA replication. EMBO J 6, 2365-2371

King CR, Swain SM, Porter L, Steinberg SM, Lippman ME, Gelman EM (1989) Heterogeneous expression of erb-B2 messenger RNA in human breast cancer. Cancer Res 49, 4185-4191

Kingston RE, Baldwin Jr AS, Sharp PA (1984) Regulation of heat shock protein 70 gene expression by c-myc. Nature 312, 280-282

Kitayama $H$, Sugimoto $Y$, Matsuzaki $T$, lkawa $Y$, Noda $M$ (1989) A ras-related gene with transformation suppressor activity. Cell 56, 77-84

Knudson Jr AG (1971) Mutation and cancer: statistical study of retinoblastoma. Proc Natl Acad Sci USA 68, 820-824

Lane DP, Crawford LV (1979) $T$ antigen is bound to a host protein in SV40-transformed cells. Nature 278, 261-263

Lee WH, Bookstein R, Hong $F$, Young LJ, Shew JY, Lee EYHP (1987) Human retinoblastoma susceptibility gene: cloning, identification and sequence. Science 235, 1394-1399

Lee EYHP, To H, Shew JH, Bookstein R, Scully P, Lee WH (1988) Inactivation of the retinoblastoma susceptibility gene in human breast cancers. Science 241, 218-242

Leppert $M$, Dobbs $M$, Scambler $P, O$ 'Connell $P$, Nakamura $Y$, Stauffer D, Woodward S, Burt R, Hughes J, Gardner E, Lathrop M, Wasmuth J, Lalouel JM, White R (1987) The gene for familial polyposis coli maps to the long arm of chromosome 5. Science 238, 1411-1413

Ludlow JW, De Caprio JA, Huang CM, Lee WH, Paucha E, Livingston DH (1989) SV40 large $T$ antigen binds preferentially to an underphosphorylated member of the retinoblastoma susceptibility gene product family. Cell $56,57-65$

Masuda $H$, Miller $C$, Kueffler HP, Battifora $H$, Cline MJ (1987) Rearrangement of the p53 gene in human osteogenic sarcomas. Proc Natl Acad Sci USA 84, 7716-7719
Miller C, Mohandas T, Wolf D, Prokocimer MP, Rotter V, Koeffler HP (1986) Human p53 gene localized to short arm of chromosome 17. Nature 319, 783-784

Morrison DK, Kaplan DR, Rapp U, Roberts TM (1988) Signal transduction from membrane to cytoplasm: growth factors and membranebound oncogene products increase c-raf phosphorylation and associated protein kinase activity. Proc Natl Acad Sci USA 85, 8855-8859

Murphree AL, Benedict WF (1984) Retinoblastoma: clues to human oncogenesis. Science 223, 1028-1033

Onclercq $R$, Gilardi P, Lavenu A, Cremisi C (1988) c-myc products trans-activate the adenovirus E4 promoter in EC stem cells by using the same target sequence as E1 A products. $J$ Virol $62,4533-4537$

Parada LF, Land H, Weinberg RA, Wolf D, Potter $V$ (1984) Co-operation between gene encoding p53 tumor antigen and ras in cellular transformation. Nature 312, 649-651

Pizon V, Chardin P, Lerosey I, Olofsson B, Tavitian A (1988) Human cDNAs rap 1 and rap 2 homologous to the Drosophila gene Dras3 encode proteins closely related to ras in the effector region. Oncogene 3, 201-204

Prendergast GC, Cole MD (1989) Posttranscriptional regulation of cellular gene expression by the c-myc oncogene. Mol Cell Biol 9, 124-134

Sarnow P, Ho YS, Williams J, Levine AJ (1982) Adenovirus E1b-58kd tumor antigen and SV40 $T$ are physically associated with the same $54 \mathrm{kd}$ cellular protein in transformed cells. Cell 28, 387-394

Slamon DJ, Clark GM, Wong SG, Levin WJ, UIIrich A, McGuire WL (1987) Human breast cancer: correlation of relapse and survival with amplification of the HER-2/neu oncogene. Science 235, 177-182

Sporn MB, Roberts AB (1988) Peptide growth factors are multifunctional. Nature 332, 217219

Stanbridge EJ (1987) Genetic regulation of tumorigenic expression in somatic cell hybrids. Adv Viral Oncol 6, 83-101

T'Ang A, Varley JM, Chakraborty S, Murphree AL, Fung YKT (1988) Structural rearrangements of the retinoblastoma gene in human breast carcinoma. Science 242, 263-266 
T'Ang A, Wu KJ, Hashimoto T, Liu WY, Takahashi $R$, Shi $X H$, Nihara $K$, Zhang $F H$, Chen YY, Du C, Qian J, Lin YG, Murphree AL, Qiu WR, Thompson T, Benedict WF, Fung YK (1989) Genomic organisation of the human retinoblastoma gene. Oncogene 4, 401-407

Tsuda $\mathrm{H}$, Hirohashi S, Shimosato $\mathrm{Y}$, Hirota $T$, Tsugane S, Yamamoto H, Niyajima N, Toyoshima K, Yamamoto T, Yokota J, Yoshida $T$, Sakamoto $H$, Terada M, Sugimura $T$ (1989) Correlation between long-term survival in breast cancer patients and amplification of two putative oncogene-coamplification units: hst-1/int-2 and c-erb-B-2/ear-1. Cancer Res 49, 3104-3108

Veillette A, Brookman MA, Horak EM, Samelson LE, Bolen JB (1989) Signal transduction through the CD4 receptor involves the activation of the internal membrane tyrosineprotein kinase p56 kck. Nature 338, 257-259

Vogelstein B, Fearon ER, Hamilton SR, Kern SE, Preisinger AC, Leppert M, Nakamura $Y$,
White R, Smits AMM, Bos JL (1988) Genetic alterations during colorectal-tumor development. N Engl J Med 319, 525-532

Wasylyk C, Wasylyk B, Heidecker G, Huleihel $M$, Rapp UR (1989) Expression of raf oncogene activates the PEA1 transcription factor motif. Mol Cell Biol 9, 2247-2250

Whyte P, Buchkovich RJ, Horowitz JM, Friend SH, Raybuck M, Weinberg RA, Harlow E (1988) Association between an oncogene and an anti-oncogene: the adenovirus E1A proteins bind to the retinoblastoma gene product. Nature 334, 124-129

Wolf D, Rotter V (1985) Major deletions in the gene encoding the p53 tumor antigen cause lack of p53 expression in HL-60 ceils. Proc Natl Acad Sci USA 82, 790-794

Wright $C$, Angus $B$, Nicholson $S$, Sainsbury JRC, Cairns J, Gullick WJ, Kelly P, Harris AL, Horne CHW (1989) Expression of c-erb B-2 oncoprotein: a prognostic indicator in human breast cancer. Cancer Res 49, 2087-2090 